\title{
Meta-analysis of multiple microarray datasets reveals a common gene signature of metastasis in solid tumors
}

Marla H Daves ${ }^{1,2}$, Susan G Hilsenbeck ${ }^{1,3}$, Ching C Lau ${ }^{1,2}$ and Tsz-Kwong Man 1,2*

\begin{abstract}
Background: Metastasis is the number one cause of cancer deaths. Expression microarrays have been widely used to study metastasis in various types of cancer. We hypothesize that a meta-analysis of publicly available gene expression datasets in various tumor types can identify a signature of metastasis that is common to multiple tumor types. This common signature of metastasis may help us to understand the shared steps in the metastatic process and identify useful biomarkers that could predict metastatic risk.

Methods: We identified 18 publicly available gene expression datasets in the Oncomine database comparing distant metastases to primary tumors in various solid tumors which met our eligibility criteria. We performed a meta-analysis using a modified permutation counting method in order to obtain a common gene signature of metastasis. We then validated this signature in independent datasets using gene set expression comparison analysis with the LS-statistic.
\end{abstract}

Results: A common metastatic signature of 79 genes was identified in the metastatic lesions compared with primaries with a False Discovery Proportion of less than 0.1. Interestingly, all the genes in the signature, except one, were significantly down-regulated, suggesting that overcoming metastatic suppression may be a key feature common to all metastatic tumors. Pathway analysis of the significant genes showed that the genes were involved in known metastasis-associated pathways, such as integrin signaling, calcium signaling, and VEGF signaling. To validate the signature, we used an additional six expression datasets that were not used in the discovery study. Our results showed that the signature was significantly enriched in four validation sets with p-values less than 0.05.

Conclusions: We have modified a previously published meta-analysis method and identified a common metastatic signature by comparing primary tumors versus metastases in various tumor types. This approach, as well as the gene signature identified, provides important insights to the common metastatic process and a foundation for future discoveries that could have broad application, such as drug discovery, metastasis prediction, and mechanistic studies.

\section{Background}

Metastasis, the process involving the spread of cancer, accounts for greater than $90 \%$ of cancer deaths [1]. However, therapies to treat those patients with advanced disease are largely ineffective. It is, therefore, imperative that we improve the understanding of the metastatic process and detect patients at risk for developing

\footnotetext{
* Correspondence: ctman@txch.org

'Dan L. Duncan Cancer Center, Baylor College of Medicine, One Baylor Plaza, Houston, Texas, 77030, USA

Full list of author information is available at the end of the article
}

metastatic disease early, in order to intervene earlier and improve their survival [2].

Metastasis is a complex process involving many steps. For example, in order to form a clinically significant metastasis through the hematogenous route, a cancer cell must detach from the cells surrounding it (a process known as the epithelial to mesenchymal transition or EMT), invade the surrounding extracellular matrix, enter and survive in the peripheral circulation, exit the circulation in an organ suitable for metastasis, and then survive and proliferate in the new environment [3]. A cancer cell has to accumulate many genetic and

\section{() Biomed Central}


epigenetic alterations in order to acquire all of the above functions necessary to become metastatic. Many of these alterations may manifest themselves though altered gene expression. The interruption of any one or more of these steps could potentially inhibit the development of clinically significant metastasis [3]. More than 32 genes that are important in suppressing the development of metastasis in one or more human cancers have been identified to date [4].

\section{Rationale}

While different cancer types do not necessarily have the same genetic program for metastasis, Ramaswamy et al described a single molecular signature of metastasis, identified in the comparison of metastatic and nonmetastatic adenocarcinomas, that could predict outcomes in various cancers, including breast, prostate, and even medulloblastoma, a non-epithelial pediatric brain tumor [5]. It was therefore our hypothesis that there are common genes and pathways of metastasis shared by multiple cancer types, and that by expanding the above analysis to incorporate more or diverse tumor types, we would be able to identify more reliable genes and pathways involved in these common steps.

The large number of expression microarray datasets in the public domain provides a rich resource for genomewide information on cancer and affords an opportunity to perform meta-analysis with a large number of cases. Meta-analysis consists of statistical techniques to combine results from several studies in order to increase statistical power and reproducibility compared with any single study [6]. Rhodes et al successfully used metaanalysis to identify a common transcriptional profile that is universally activated in most cancer types relative to the normal tissues from which they arose, likely reflecting essential transcriptional features of neoplastic transformation [7]. Parmigiani et al also successfully applied meta-analysis of gene expression to the molecular classification of lung cancer [8].

\section{Objectives}

In this study, we hypothesize that a meta-analysis of publicly available genomic expression datasets of various cancer types can identify a common metastatic signature of metastasis. We tested this hypothesis by implementing and applying a modified permutation meta-analysis method on multiple microarray datasets and then validated the signature in independent datasets.

\section{Methods}

\section{Eligibility Criteria}

We searched the public cancer microarray database, Oncomine [9], to identify expression microarray datasets that compared the expression of primary tumors versus distant metastases of various cancer types. In order to be included in our study, a dataset was required to (1) be generated from human tumors, (2) compare primary tumors versus distant metastatic tumors, (3) have at least one significant gene with a Q-value $<0.1$, and (4) not include samples that overlapped with those of another identified dataset. In addition, we eliminated two datasets with $>50 \%$ of the tested genes with Qvalues $<0.1$ because of a potential quality issue with the dataset.

\section{Information sources}

Oncomine is the most comprehensive cancer-specific database currently containing 512 datasets investigating 35 tumor types $[9,10]$. This database was an excellent source of datasets for this study because the datasets contained additional sample information, which was easily accessible and analyzable. The data obtained is processed by the Oncomine team prior to export. Expression values are log-transformed and median-centered per array. Differential expression is identified by a permutation test with shrinkage to reduce the noise in the data, and false discovery rates $(\mathrm{Q}$-value $=\mathrm{NP} / \mathrm{R}$, where $\mathrm{P}$ is the $\mathrm{p}$-value, $\mathrm{N}$ is the total number of genes analyzed, and $\mathrm{R}$ is the sorted rank of $\mathrm{P}$ ) are calculated to correct for multiple testing [11].

\section{Search/Study selection}

We performed a simple search for the search term "met" and obtained 42 studies of which 5 were quickly eliminated as being non-human studies or for having evaluated late metastases on primary tumors, instead of having a sample from the metastasis. We then identified 37 studies [5,12-43] in the Oncomine database that were analyzed on the basis of primary tumor versus metastasis. Cited literature was reviewed to confirm that the analysis was as documented in the Oncomine database.

\section{Data collection process/Data items}

For each of the identified studies, data for all genes with a Q-value less than 0.1 were extracted from the database as a .csv file. Since Oncomine does not allow the export of the raw data, the extracted data included gene symbol, reporter ID, mean expression levels in the primary and metastatic tumors, $\mathrm{p}$-value, and calculated Q-value of each feature or gene.

\section{Summary measures}

Since the raw data were not available for some of these studies, we decided to use a counting method that could make us of the differential expression information from the Oncomine database for the meta-analysis. We modified a meta-analysis method that was originally reported by Rhodes et al. [7] and implemented it in the $R$ 
statistical computing environment [44]. This method essentially counts the number of datasets in which each gene is significantly differentially expressed and performs permutations in order to determine the significance of being differentially expressed in each number of studies. Our improvement on the method involved the definition of the False Discovery Proportion (FDP) which was a cumulative measure of the false discovery rate that smoothed the curve as the number of repeated genes decreased and was more sensitive in identifying genes of interest than the original method based on comparative analysis of the two methods. This measure, $\mathrm{FDP}_{\mathrm{k}}$, is the number of genes present in $\mathrm{k}$ or more studies as found by random permutation divided by the observed number of genes present in $\mathrm{k}$ or more studies. The code for this implementation is available upon request. The algorithm included the following steps:

- A set of $S$ differential expression datasets was selected.

- For each dataset, two signatures were created. One consisted of unique genes that were under-expressed metastases versus primary tumors in the dataset with a $\mathrm{Q}$-value $<0.1$, and the other consisted of those unique genes over-expressed with a $\mathrm{Q}$-value $<$ 0.1 .

- Each of the following steps of the algorithm was performed separately for the over- and underexpressed genes.

- For each gene, the number of signatures (from 0 to $S$ ) in which it was present was counted (i.e. the number of studies in which it was significantly differentially expressed between primary and metastases.)

- The total number of genes, $O_{j}$, present in exactly $j$ signatures was tallied $\left(O_{1}, O_{2}, \ldots, O_{S}\right)$. (For a hypothetical example, see Figure 1.)

- Random permutations were performed in which the same set of Q-values was randomly assigned to the unique genes within each study, so that the set of genes in each signature changed at random, but the number of significant genes in each individual study and the genes at risk for inclusion remained the same.

- Each permutation generated a tally of the number of genes, $E_{j}$, found to be present in $\mathrm{j}$ random signatures by chance alone $\left(E_{1}, E_{2}, \ldots, E_{S}\right)$

- The procedure was repeated 1000 times resulting in a matrix $E_{i j}$ where $i$ was the permutation and $j$ was the number of signatures

- A False Discovery Proportion was calculated for each number of studies $k$ where

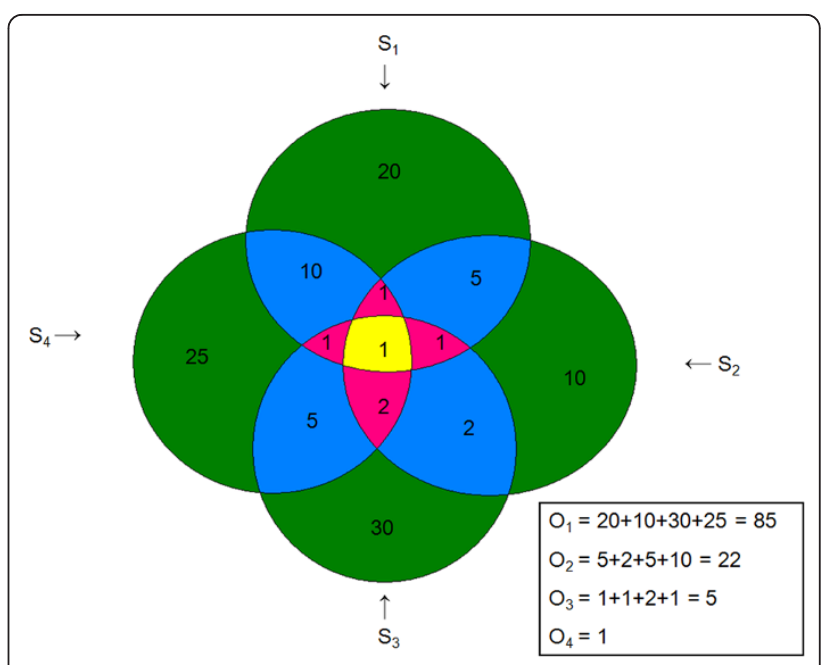

Figure 1 Example of the identification of the $O_{i}$ in the metaanalysis method. Each of the circles represents a hypothetical dataset $\left(S_{1}\right.$ to $\left.S_{4}\right)$. The numerals are the number of genes differentially expressed in the datasets represented by that area of overlap of the circles. The value $O_{i}$ is defined as the number of genes differentially expressed in exactly $i$ number of datasets. In the example, $O_{1}$ is 85 since that is the number of genes differentially expressed in 1 study, whereas $\mathrm{O}_{4}$ is 1 since only one gene is present in the area overlapping all 4 studies.

$$
\mathrm{FDP}_{k}=\frac{\sum_{\mathrm{j}=\mathrm{k}}^{S}\left(\sum_{1}^{1000} \mathrm{E}_{\mathrm{i}, \mathrm{j}} / 1000\right)}{\sum_{\mathrm{j}=\mathrm{k}}^{S} \mathrm{O}_{\mathrm{j}}}
$$

- An FDP $<0.1$ was considered significant. The genes that met the FDP cutoff were selected as the common metastatic signature of metastasis.

\section{Other analyses}

\section{Pathway analysis}

Using the commercial pathways knowledge database Ingenuity Pathways Analysis (IPA), we identified canonical pathways that were enriched or over-represented in the common metastatic signature [45]. Canonical pathway analysis identified the pathways from the IPA library of canonical pathways that were most significant to the metastatic signature. Genes in the signature of metastasis that were associated with a canonical pathway in Ingenuity's Knowledge Base were considered for the analysis. The significance of the association between the signature and the canonical pathway was measured in 3 ways: 1) A ratio of the number of genes from the 
signature that map to the pathway divided by the total number of genes that map to the canonical pathway was calculated; 2) A right-sided Fisher's exact test was used to calculate a p-value determining the probability that the association between the genes in the dataset and the canonical pathway is explained by chance alone; 3) Benjamini-Hochberg (B-H) method of multiple testing correction was performed [46]. We then performed PubMed literature review to test if the pathways that were significant with a B-H p-value less than 0.05 had been previously implicated in metastasis and mapped these pathways to the known metastatic cascade.

\section{Validation}

In order to perform bioinformatic validation of the gene signature, we downloaded the raw data for the ten studies identified in the Oncomine database that were reserved for validation as described above. After importing and processing the raw data in BRB-ArrayTools v3.7.0 [47], we used the Gene Set Expression Comparison tool to compute the LS statistic p-value for our metastatic signature for each study. The LS statistic tests whether the average degree of differential expression is greater than expected from a random sample of genes. For a set of $N$ genes, the LS statistic is defined as

$$
L S=\frac{\sum_{\mathrm{i}=1}^{\mathrm{N}}\left(-\log \left(\mathrm{p}_{\mathrm{i}}\right)\right)}{\mathrm{N}}
$$

where the $p_{i}$ are the $\mathrm{p}$-values of the appropriate single gene univariate test. The statistical significance of a gene set, i.e. the LS statistic p-value, is then determined by comparison of the LS statistic to the empirical distribution of LS in random samples of $N$ genes. If significant, it provides evidence that the genes within our metastatic signature are differentially expressed between primary tumors and metastases within the validation dataset more often than would be expected by chance alone [48]. This was performed separately for our up-regulated and down-regulated genes. For instance, for the downregulated genes, the metastatic signature down-regulated genes were analyzed in a filtered list of all the downregulated genes in the validation dataset.

\section{Results}

\section{Study Selection}

The datasets were obtained from Oncomine, and eligible datasets were selected as outlined in Figure 2. Two were eliminated for potentially having overlapping data with a previously identified dataset $[5,35]$. Thirty of the remaining datasets ( $81 \%$ of the initial 37 datasets) were found to have significantly altered genes with a Q-value $<0.1$. Twenty eight of these $(75.6 \%$ of the initial 37 datasets) met our

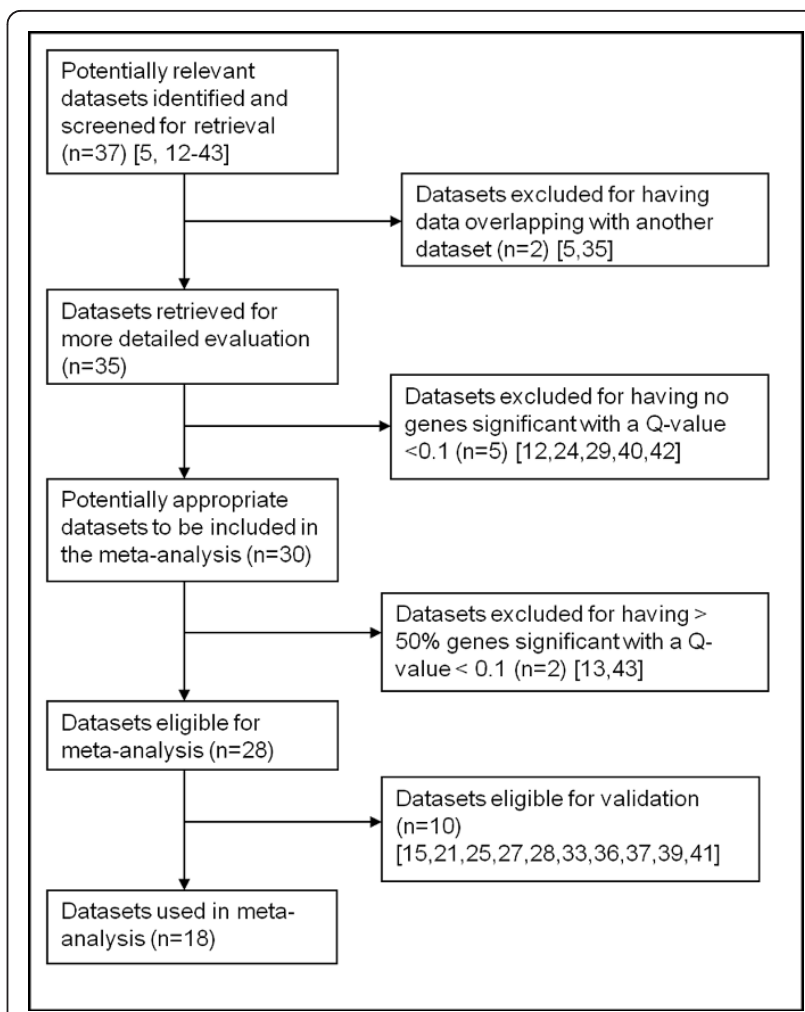

Figure 2 Flow diagram of the selection of datasets included in the meta-analysis. After initial screening and identification of potential datasets in the Oncomine database, the process of elimination of ineligible studies is outlined. $n$ : number of datasets in a specific category; numbers in brackets: reference for the dataset.

eligibility criteria and were included in this analysis. The eligible datasets analyzed the genomic expression of primary tumors versus metastases in multiple different tumor types including melanoma and sarcomas, in addition to various adenocarcinomas. We then set aside ten datasets that had downloadable raw data in the Gene Expression Omnibus (GEO) [49] or the Stanford Microarray Database (SMD) [50] for possible use as validation sets. Upon further review, four validation datasets were eliminated for reasons outlined in Figure 3. The eligible datasets involved various tumor types, including colon cancer, prostate cancer, melanoma, sarcoma, and ovarian cancer.

\section{Study characteristics}

The datasets that were selected for analysis along with their respective number of unique genes tested and the number of genes with a Q-value less than 0.1 are listed in Table 1. The references and accession numbers are also provided in the table.

\section{Synthesis of results}

To identify a common metastatic signature in solid tumors, we implemented a modified permutation 


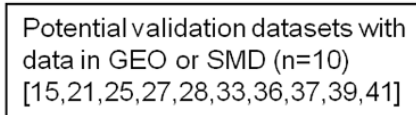

Figure 3 Flow diagram of the selection of studies included for validation. The process of selection of possible validation datasets is outlined. n: number of datasets in a specific category; numbers in brackets: reference for the dataset described; GEO: Gene Expression Omnibus [49]; SMD: Stanford Microarray Database [50].

counting method in the $\mathrm{R}$ statistical environment in order to perform a meta-analysis of 18 publicly available expression microarray datasets extracted from the Oncomine database (Table 1). Based on the meta-analysis, we discovered that down-regulated genes that were present in four or more studies and up-regulated genes in five or more studies were more prevalent than would be expected by chance alone with a False Discovery Proportion (FDP) of less than 0.1 (See Figure 4). Interestingly, we identified $78(44+27+6+1)$ down-regulated genes and only 1 up-regulated gene in metastases compared with primary tumors. These differentially expressed genes constituted a common signature of metastasis and are listed in Table 2. As expected, those datasets that had more differentially expressed genes contributed more to the metastatic signature than those with fewer genes (See Figure 5). However, all but three of the datasets contributed at least one gene to the common metastatic signature. The specific datasets in which a specific signature gene was significant with a FDP $<$ 0.1 are listed in the Table 3 .

This study expanded upon the previous study by Ramaswamy et al by including multiple cancer types, as opposed to only adenocarcinomas [5]. Our method was able to capture 5 of the 17 genes in the Ramaswamy metastatic signature. These genes were found to be down-regulated in both signatures: ACTG2, MYLK, MYH11, CNN1, and NR4A2. The only up-regulated gene, EZH2, identified in our study was not part of the Ramaswamy signature though the gene was up-regulated with respect to metastasis in the Ramaswamy Multi-cancer dataset comparing primary tumors versus metastases in Oncomine with a Q-value of 0.05 . This suggests that our meta-analysis procedure may identify additional metastatic genes that have not been reported before, but are supported by multiple expression studies.

\section{Other analyses \\ Pathway analysis of genes involved in the common metastatic signature}

To validate whether this signature contains metastasis information, we identified the pathways that are significantly enriched in the signature. Ingenuity Pathway Analysis revealed that the down-regulated genes in the metastatic signature were enriched in many pathways previously implicated in metastasis, such as integrin signaling, calcium signaling, and VEGF signaling. The significant pathways are shown in Table 4. In order to determine whether these pathways were potentially specific to the EMT, and therefore epithelial tumors, or whether they could represent common steps that could be shared with non-epithelial tumors, we mapped these pathways to steps in the metastatic cascade in which they had been previously implicated in the literature. Interestingly, each one of the steps in the metastatic cascade has been reported to be associated with one or more of our significant pathways (See Figure 6), suggesting the metastatic signature potentially contains information throughout the whole metastatic cascade.

\section{Validation of the common metastatic signature}

To validate that the common metastatic signature could be applied to other metastatic datasets, we performed Gene Set Expression Comparison analysis on six independent gene expression datasets identified through Oncomine that were not used in the meta-analysis. We found that the common metastatic signature was significantly enriched in four out of six of the publicly available datasets (See Table 5). The signature was enriched, with an LS statistic $\mathrm{p}$-value $<0.05$, in prostate cancer, gastric cancer, colon cancer, and melanoma datasets $[15,21,33,39]$. This supports our hypothesis that this common metastatic signature is enriched in multiple tumor types. There were two datasets, an ovarian and sarcoma dataset, tested in which the common metastatic signature was not significantly enriched [25,37]. This may be due to the fact that these tumor types are not well represented in our discovery set and the number of significant genes of these tumor types in the discovery sets is not high. We did attempt to vary the Q-value cutoff from 0.01 to 0.2 in order to vary the number of significant genes represented from these datasets, but this did not improve the validation results. Further studies may need to be performed to test this possibility 
Table 1 Expression microarray studies used in the meta-analysis

\begin{tabular}{|c|c|c|c|c|c|c|c|c|}
\hline & Study [Reference] & Platform & $\begin{array}{l}\text { Unique Genes } \\
\text { Tested }\end{array}$ & $\begin{array}{l}\text { Genes Sig Up } \\
\text { (\% of tested) }\end{array}$ & $\begin{array}{l}\text { Genes Sig } \\
\text { Down } \\
\text { (\% of tested) }\end{array}$ & $\begin{array}{l}\text { Primary } \\
\text { tumors }\end{array}$ & $\begin{array}{l}\text { Distant } \\
\text { Mets }\end{array}$ & $\begin{array}{l}\text { GEO } \\
\text { Accession }\end{array}$ \\
\hline 1 & Bittner Breast [14] & HG U133 Plus 2.0 & 19079 & $\begin{array}{l}33 \\
(0.2 \%)\end{array}$ & $\begin{array}{l}0 \\
(0 \%)\end{array}$ & 327 & 9 & GSE2109 \\
\hline 2 & Bittner Colon [14] & HG U133 Plus 2.0 & 19079 & $\begin{array}{l}656 \\
(3.4 \%)\end{array}$ & $\begin{array}{l}3938 \\
(20.6 \%)\end{array}$ & 330 & 43 & GSE2109 \\
\hline 3 & Bittner Lung [14] & HG U133 Plus 2.0 & 19079 & $\begin{array}{l}127 \\
(0.6 \%)\end{array}$ & $\begin{array}{l}15 \\
(0.1 \%)\end{array}$ & 101 & 8 & GSE2109 \\
\hline 4 & Bittner Ovarian [14] & HG U133 Plus 2.0 & 19079 & $\begin{array}{l}494 \\
(2.6 \%)\end{array}$ & $\begin{array}{l}131 \\
(0.7 \%)\end{array}$ & 166 & 75 & GSE2109 \\
\hline 5 & Bittner Sarcoma [14] & HG U133 Plus 2.0 & 19079 & $\begin{array}{l}4 \\
(0 \%)\end{array}$ & $\begin{array}{l}1 \\
(0 \%)\end{array}$ & 42 & 10 & GSE2109 \\
\hline 6 & Garber Lung [16] & $\begin{array}{l}\text { Institutional cDNA } \\
\text { microarray }\end{array}$ & 10723 & $\begin{array}{l}9 \\
(0.1 \%)\end{array}$ & $\begin{array}{l}57 \\
(0.5 \%)\end{array}$ & 61 & 6 & GSE3398 \\
\hline 7 & Graudens Colon [17] & $\begin{array}{l}\text { Institutional cDNA } \\
\text { microarray }\end{array}$ & 6242 & $\begin{array}{l}145 \\
(2.3 \%)\end{array}$ & $\begin{array}{l}80 \\
(1.3 \%)\end{array}$ & 18 & 30 & GSE3964 \\
\hline 8 & Haqq Melanoma [18] & $\begin{array}{l}\text { Research Genetics cDNA } \\
\text { microarray }\end{array}$ & 7344 & $\begin{array}{l}420 \\
(5.7 \%)\end{array}$ & $\begin{array}{l}639 \\
(8.7 \%)\end{array}$ & 6 & 19 & N/A \\
\hline 9 & $\begin{array}{l}\text { Holzbeierlein Prostate } \\
\text { [19] }\end{array}$ & HG U95A-Av2 & 7820 & $\begin{array}{l}11 \\
(0.1 \%)\end{array}$ & $\begin{array}{l}295 \\
(3.8 \%)\end{array}$ & 40 & 9 & N/A \\
\hline 10 & Jain Endocrine [20] & HG U95A-Av2 & 7820 & $\begin{array}{l}14 \\
(0.2 \%)\end{array}$ & $\begin{array}{l}229 \\
(2.9 \%)\end{array}$ & 8 & 17 & N/A \\
\hline 11 & Lapointe Prostate [22] & $\begin{array}{l}\text { Institutional cDNA } \\
\text { microarray }\end{array}$ & 10021 & $\begin{array}{l}1081 \\
(10.8 \%)\end{array}$ & $\begin{array}{l}1219 \\
(12.2 \%)\end{array}$ & 62 & 9 & GSE3933 \\
\hline 12 & $\begin{array}{l}\text { LaTulippe Prostate } \\
\text { [23] }\end{array}$ & HG U95A-Av2 & 7820 & $\begin{array}{l}265 \\
(3.4 \%)\end{array}$ & $\begin{array}{l}245 \\
(3.1 \%)\end{array}$ & 23 & 9 & N/A \\
\hline 13 & Magee Prostate [26] & $\mathrm{HG} F L$ & 4564 & $\begin{array}{l}35 \\
(0.8 \%)\end{array}$ & $\begin{array}{l}18 \\
(0.4 \%)\end{array}$ & 8 & 3 & N/A \\
\hline 14 & O'Donnell Oral [30] & HG U133A & 12427 & $\begin{array}{l}1 \\
(0 \%)\end{array}$ & $\begin{array}{l}28 \\
(0.2 \%)\end{array}$ & 22 & 5 & GSE2280 \\
\hline 15 & Radvanyi Breast [31] & Custom cDNA microarray & 16133 & $\begin{array}{l}548 \\
(3.3 \%)\end{array}$ & $\begin{array}{l}85 \\
(0.5 \%)\end{array}$ & 47 & 7 & GSE1477 \\
\hline 16 & $\begin{array}{l}\text { Ramaswamy } \\
\text { Multicancer [32] }\end{array}$ & HG FL, Hu35KsubA & 9064 & $\begin{array}{l}556 \\
(3.4 \%)\end{array}$ & $\begin{array}{l}301 \\
(3.3 \%)\end{array}$ & 10 & 4 & N/A \\
\hline 17 & Segal Sarcoma [34] & HG U95A-Av2 & 7820 & $\begin{array}{l}168 \\
(2.1 \%)\end{array}$ & $\begin{array}{l}164 \\
(2.1 \%)\end{array}$ & 29 & 4 & N/A \\
\hline 18 & Vanaja Prostate [38] & $\begin{array}{l}\text { HG U133A, } \\
\text { HG U133B }\end{array}$ & 17358 & $\begin{array}{l}4 \\
(0 \%)\end{array}$ & $\begin{array}{l}208 \\
(1.2 \%)\end{array}$ & 27 & 5 & N/A \\
\hline
\end{tabular}

The 18 datasets used in the meta-analysis are described with regard to the platform used in the original experiment, the number of unique genes represented in the platform, the number of genes significantly (sig) dysregulated in metastases compared with primaries with a Q-value $<0.1$, the number of samples that are primary tumors or distant metastases (mets), and the Gene Expression Omnibus (GEO) Accession number. HG U133 Plus 2: Affymetrix Human Genome U133 Plus 2.0 Array; HG U95A0Av2: Affymetrix Human Genome U95A-Av2 Array; HG FL: Affymetrix HumanGeneFL Array; HG U133A: Affymetrix Human Genome U133A

Array: HG U133B: Affymetrix Human Genome U133B Array; N/A: Not applicable.

when more of datasets of these tumor types are available. However, the common metastatic signature was enriched in other tumor types that were underrepresented in our meta-analysis, such as gastric cancer that was not present in the discovery set, suggesting that the validation results are not simply due to the presence or absence of the same tumor types in the discovery and validation sets.

\section{Discussion}

\section{Summary of the evidence}

We have used a meta-analysis method to identify genes are shared and important in metastasis. The fact that these genes are involved in pathways that have been previously implicated in metastasis supports their involvement in the metastatic process. These genes may be useful as potential therapeutic targets or predicting clinical outcome. Since these genes and pathways are common to multiple tumor types as shown by the fact that they are enriched in various tumors, these may be targets that can be exploited in many different tumors. Drug discovery could be performed by finding inhibitors of identified pathways, such as FAK inhibitors.

One promising in silico approach of drug discovery is the use of the Connectivity Map to find drugs that can reverse a gene signature, such as the common metastatic 


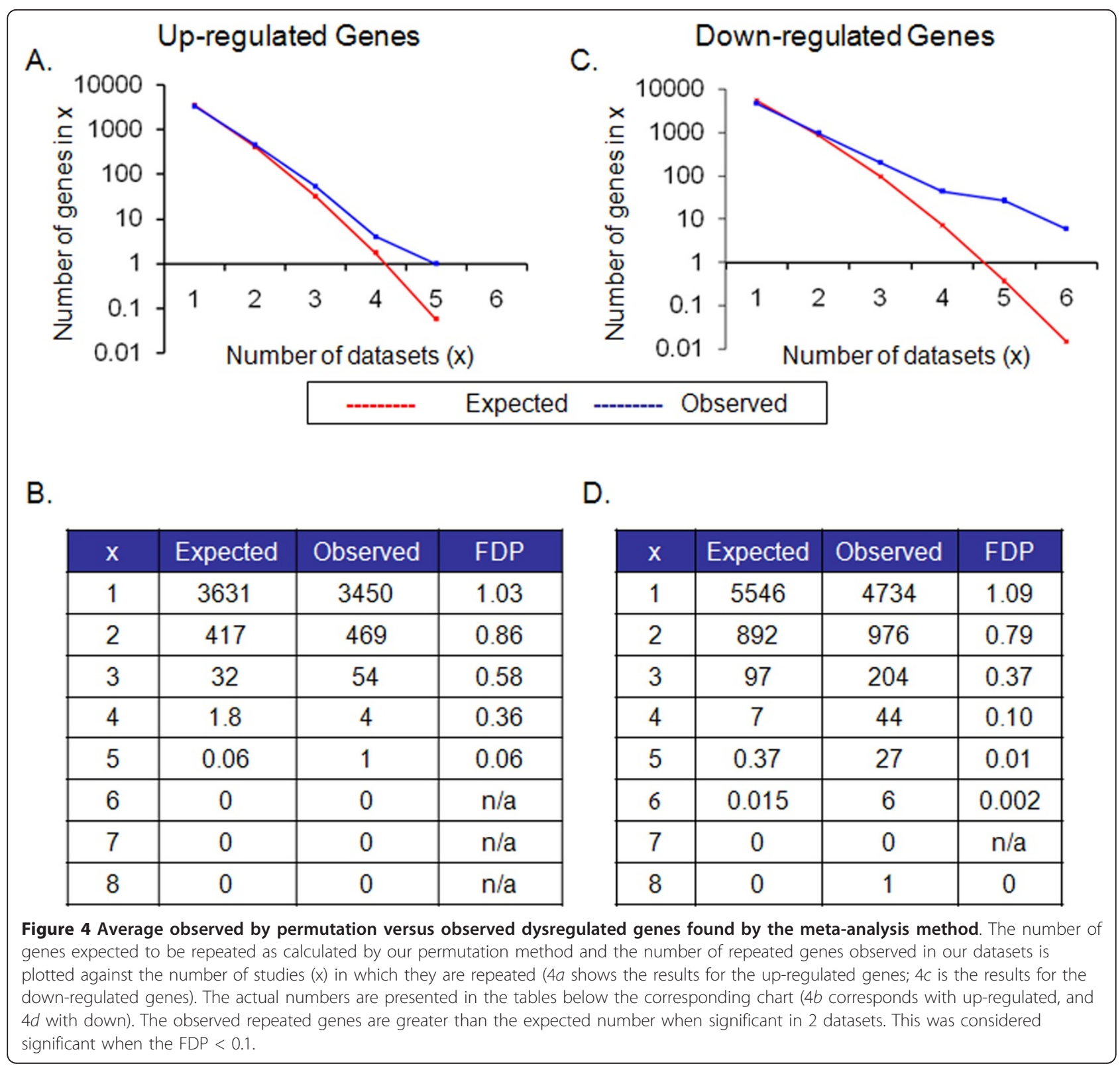

signature, and as a result potentially reverse the metastatic phenotype [51,52]. On preliminary analysis of the metastatic signature by the Connectivity Map, the top molecule that could reverse the common metastatic signature by the permutation analysis was camptothecin. Camptothecin is a topoisomerase I inhibitor that has been shown to induce apoptosis in tumor cells. Irinotecan and topotecan, which are analogs of camptothecin, are currently being used to treat several cancers including colon cancer, ovarian cancer, and gliomas [53]. Interestingly, when ranking the drugs by Anatomical Therapeutic Chemical (ATC) codes, the top three ranking codes were all groups of antipsychotics, which may be related to the ability of some of these compounds to induce autophagy in experimental models [54]. The molecules in these groups were significantly associated with reversal of the metastatic signature with good specificity for the signature. This may represent known and readily available drugs that could have a new application immediately without the need of developing a new compound, which would take many years of testing. The result of this in silico analysis can only be confirmed with more analyses and experiments; however, this shows the promise of applying this signature to the prediction and therapy of metastatic cancers for improving the outcomes of patients.

Though all of the genes in our signature were differentially expressed in more studies than would be expected by chance alone, it is important to note that 
Table 2 The Common Metastatic Signature

\begin{tabular}{|c|c|c|c|c|c|}
\hline $\begin{array}{l}\text { Number of } \\
\text { studies repeated }\end{array}$ & $\begin{array}{l}\text { Up-regulated } \\
\text { in metastasis }\end{array}$ & $\begin{array}{l}\text { Down-regulated } \\
\text { in metastasis }\end{array}$ & & & \\
\hline \multirow[t]{11}{*}{4 studies } & Not significant & ACTG2 & GJA1 & NBL1 & RARRES1 \\
\hline & & CASP7 & GNG12 & PAGE4 & SELE \\
\hline & & CSRP1 & GSN & PAM & SLC12A4 \\
\hline & & CYR61 & IER2 & PCP4 & SMTN \\
\hline & & DPT & ISL1 & PDE4D & SORBS1 \\
\hline & & DSTN & JMJD3 & $\mathrm{PIGB}$ & SYNPO2 \\
\hline & & FILIP1L & JUNB & PKIG & TCF21 \\
\hline & & FLNC & KRT15 & PLA2G2A & TMEM49 \\
\hline & & FOSB & LUM & PLEKHC1 & TPM1 \\
\hline & & FUCA1 & MAPK1 & PPP1R12A & TSC22D1 \\
\hline & & GADD45B & MFAP4 & RAP1A & VCL \\
\hline \multirow[t]{7}{*}{5 studies } & $\mathrm{EZH} 2$ & ACTA2 & DKFZP56400823 & LMOD1 & RBPMS \\
\hline & & BMPR1A & DMN & MCL1 & SPARCL1 \\
\hline & & CAMK2G & FBLN1 & MGP & SPG20 \\
\hline & & CCND2 & FHL1 & NR4A1 & TACC1 \\
\hline & & CNN1 & FXYD3 & NR4A3 & TAGLN \\
\hline & & CTGF & HBEGF & PPP1R12B & ZFP36 \\
\hline & & $\mathrm{DlO} 2$ & KCNMA1 & PYROXD1 & \\
\hline \multirow[t]{2}{*}{6 studies } & None & BTG2 & KCNMB1 & MYLK & \\
\hline & & JUND & MYH11 & SOD3 & \\
\hline 8 studies & None & TPM2 & & & \\
\hline
\end{tabular}

The gene symbols of the genes in the metastatic signature are given with along with the number of studies in which it was significant.

none of the genes in the common metastatic signature were present in more than 8 of our 18 datasets. This could be caused by many factors, such as heterogeneity of metastatic tumors, dataset quality, and the use of different platforms without uniform representation of genes of interest. This may explain the difficulty many individuals have found in identifying overlapping genes in multiple datasets examining metastasis [55]. In addition, more overlapping genes may not have been

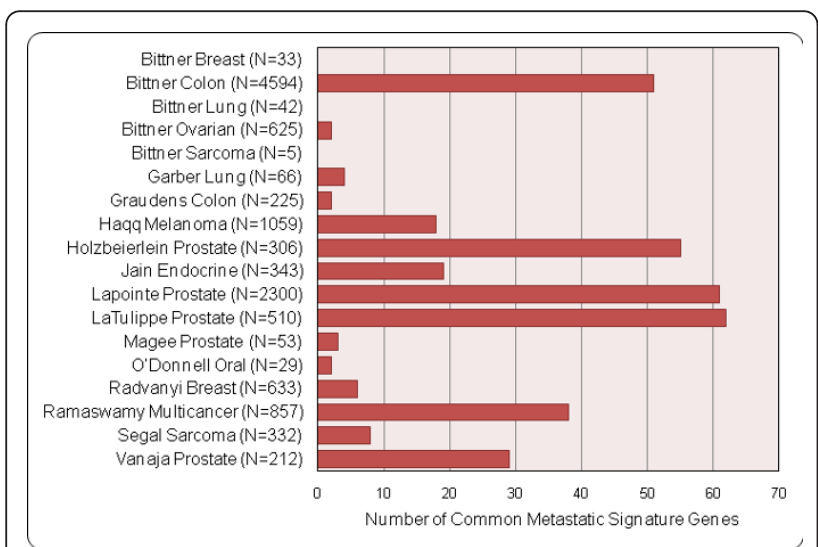

Figure 5 Number of genes in the common metastatic signature significant $(\mathrm{Q}-\mathrm{value}<\mathbf{0 . 1})$ in each dataset. N: Number of unique genes differentially expressed with a Q-value $<0.1$. identified because of a potential lack of power caused by using a stringent Q-value of 0.1. However, this highlights the usefulness of the meta-analysis approach in identifying significant metastatic genes that repeat more than expected by chance that may not be identified when initially comparing datasets.

In our analysis, we have also noted that the number of down-regulated genes is much greater than the number of up-regulated genes. This intriguing observation suggests that overcoming metastatic suppression may be a critical or common step in tumor progression. Alternatively, the genes involved in metastasis suppression may be more similar and shared among the solid tumors than those involved in metastasis activation processes. It has been previously shown that down-regulation of certain genes, such as KISS1, RhoGDI2, and nm23-H1, is important in metastasis [56]. At least one of our identified down-regulated genes, CDGF, is a recognized metastasis suppressor gene [4]. In addition, two of the most highly dysregulated pathways, the actin cytoskeleton signaling pathway and the regulation of actin motility by Rho, have been associated with multiple metastasis suppressor genes [56]. We expect that further functional studies of the down-regulated genes in our common signature will reveal novel metastasis suppressor genes.

The future applications of this meta-analysis method are numerous, as the number of gene expression 
Table 3 Datasets in which genes in common metastatic signature of metastasis are significant with a $\mathbf{Q}<0.1$

\begin{tabular}{|c|c|c|c|c|c|c|c|c|c|c|c|c|c|c|c|c|c|c|c|}
\hline $\begin{array}{l}\text { Genes differentially } \\
\text { expressed in metastasis }\end{array}$ & 1 & 2 & 3 & 4 & 5 & 6 & 7 & 8 & 9 & 10 & 11 & 12 & 13 & 14 & 15 & 16 & 17 & 18 & Num studies \\
\hline \multicolumn{20}{|l|}{ Up - regulated genes } \\
\hline $\mathrm{EZH} 2$ & & & & & & & & & & & $x$ & $x$ & $x$ & & $x$ & $x$ & & & 5 \\
\hline \multicolumn{20}{|l|}{ Down - regulated genes } \\
\hline ACTG2 & & $x$ & & & & & $x$ & & & & $x$ & & & & & & & $x$ & 4 \\
\hline FUCA1 & & & & & & & & $x$ & & $x$ & $x$ & $x$ & & & & & & & 4 \\
\hline JUNB & & & & & & & & & $x$ & & $x$ & $x$ & & & & $x$ & & & 4 \\
\hline PDE4D & & $x$ & & & & & & & $x$ & & $x$ & & & & & $x$ & & & 4 \\
\hline RAP1A & & $x$ & & & & & & & $x$ & & $x$ & & & & & & $x$ & & 4 \\
\hline SYNPO2 & & $x$ & & & & & & & & & $x$ & & & & & $x$ & & $x$ & 4 \\
\hline CASP7 & & $x$ & & & & & $x$ & & & & $x$ & & & & & & & $x$ & 4 \\
\hline GADD45B & & & & & & & & & $x$ & $x$ & & $x$ & & & & $x$ & & & 4 \\
\hline KRT15 & & & & & & & & & & & $x$ & $x$ & & & & $x$ & & $x$ & 4 \\
\hline PIGB & & & & & & & & $x$ & & $x$ & $x$ & & & & & & & $x$ & 4 \\
\hline RARRES1 & & $x$ & & & & & & & $x$ & & $x$ & $x$ & & & & & & & 4 \\
\hline TCF21 & & $x$ & & $x$ & & & & & & & & $x$ & & & & & & $x$ & 4 \\
\hline CSRP1 & & $x$ & & & & & & & $x$ & & & $x$ & & & & & & $x$ & 4 \\
\hline GJA1 & & & & & & & & $x$ & $x$ & $x$ & $x$ & & & & & & & & 4 \\
\hline LUM & & $x$ & & & & $x$ & & $x$ & & & $x$ & & & & & & & & 4 \\
\hline PKIG & & $x$ & & & & & & & $x$ & & & $x$ & & & & & $x$ & & 4 \\
\hline SELE & & & & & & & & & $x$ & & $x$ & $x$ & & & & & & $x$ & 4 \\
\hline TMEM49 & & & & & & & & $x$ & & & $x$ & & & & $x$ & $x$ & & & 4 \\
\hline CYR61 & & & & & & & & & $x$ & $x$ & $x$ & $x$ & & & & & & & 4 \\
\hline GNG12 & & $x$ & & & & & & & $x$ & & $x$ & & & & & $x$ & & & 4 \\
\hline MAPK1 & & $x$ & & & & & & $x$ & & & $x$ & & & & & $x$ & & & 4 \\
\hline$P L A 2 G 2 A$ & & $x$ & & & & & & & $x$ & & $x$ & $x$ & & & & & & & 4 \\
\hline SLC12A4 & & & & & & & & $x$ & & & & $x$ & & & & $x$ & & $x$ & 4 \\
\hline TPM1 & & $x$ & & & & & & & $x$ & & $x$ & $x$ & & & & & & & 4 \\
\hline DPT & & $x$ & & & & & & $x$ & & & $x$ & & & & & & $x$ & & 4 \\
\hline GSN & & $x$ & & & & & & & $x$ & & $x$ & $x$ & & & & & & & 4 \\
\hline MFAP4 & & $x$ & & & & $x$ & & & & & $x$ & $x$ & & & & & & & 4 \\
\hline PLEKHC1 & & & & & & & & & $x$ & & $x$ & $x$ & & & & $x$ & & & 4 \\
\hline SMTN & & $x$ & & & & & & & $x$ & & & $x$ & & & & & $x$ & & 4 \\
\hline TSC22D1 & & & & & & & & & $x$ & & $x$ & $x$ & & & & $x$ & & & 4 \\
\hline DSTN & & & & & & & & $x$ & $x$ & & $x$ & $x$ & & & & & & & 4 \\
\hline IER2 & & $x$ & & & & & & & $x$ & & & $x$ & & & & $x$ & & & 4 \\
\hline NBL1 & & $x$ & & & & & & & $x$ & & & $x$ & & & & $x$ & & & 4 \\
\hline PPP1R12A & & $x$ & & & & $x$ & & & $x$ & & $x$ & & & & & & & & 4 \\
\hline SORBS1 & & $x$ & & & & & & & & & $x$ & & & & & $x$ & & $x$ & 4 \\
\hline $\mathrm{VCL}$ & & $x$ & & & & & & & $x$ & & & $x$ & & & & & & $x$ & 4 \\
\hline FILIP1L & & $x$ & & & & & & & $x$ & & $x$ & $x$ & & & & & & & 4 \\
\hline ISL1 & & & & & & & & & $x$ & & $x$ & $x$ & & & & & & $x$ & 4 \\
\hline PAGE4 & & & & & & & & & & & $x$ & $x$ & & & & $x$ & & $x$ & 4 \\
\hline FLNC & & $x$ & & & & & & & & & $x$ & $x$ & & & & & & $x$ & 4 \\
\hline JMJD3 & & $x$ & & & & & & & $x$ & & & $x$ & & & & $x$ & & & 4 \\
\hline PAM & & & & & & & & $x$ & $x$ & & $x$ & & & & & $x$ & & & 4 \\
\hline FOSB & & & & & & & & & $x$ & $x$ & & $x$ & $x$ & & & & & & 4 \\
\hline PCP4 & & & & & & & & & & & $x$ & $x$ & & & & $x$ & & $x$ & 4 \\
\hline ACTA2 & & & & & & & & $x$ & $x$ & & $x$ & $x$ & & & & $x$ & & & 5 \\
\hline CNN1 & & $x$ & & & & & & $x$ & & & $x$ & $x$ & & & & & & $x$ & 5 \\
\hline DMN & & $x$ & & & & & & & & & & $x$ & & $x$ & & $x$ & & $x$ & 5 \\
\hline HBEGF & & $x$ & & & & & & $x$ & $x$ & $x$ & $x$ & & & & & & & & 5 \\
\hline
\end{tabular}


Table 3 Datasets in which genes in common metastatic signature of metastasis are significant with a $Q$ ? $<$ ? 0.1 (Continued)

\begin{tabular}{|c|c|c|c|c|c|c|c|c|c|c|c|c|c|c|c|}
\hline MGP & & & & & $x$ & & $x$ & $x$ & & & & $x$ & & $x$ & 5 \\
\hline PYRO1D1 & $x$ & & & & $x$ & & $x$ & $x$ & & & & & $x$ & & 5 \\
\hline TACC1 & $X$ & & $x$ & & $X$ & & $x$ & & & & & $x$ & & & 5 \\
\hline BMPR1A & $x$ & & & & $x$ & & $x$ & $x$ & & & & & & $x$ & 5 \\
\hline CTGF & & & & $x$ & $x$ & $x$ & $x$ & $x$ & & & & & & & 5 \\
\hline FBLN1 & $x$ & & & $x$ & $x$ & & $x$ & $x$ & & & & & & & 5 \\
\hline KCNMA1 & $x$ & & & $x$ & & & & $x$ & & & $x$ & $x$ & & & 5 \\
\hline NR4A1 & $x$ & & & & $x$ & & & $x$ & $x$ & & & $x$ & & & 5 \\
\hline RBPMS & & & & & $x$ & $x$ & $x$ & $x$ & & & & & $x$ & & 5 \\
\hline TAGLN & & & & & $x$ & & $x$ & $x$ & & & & $x$ & & $x$ & 5 \\
\hline CAMK2G & $x$ & & & & $x$ & $x$ & & $x$ & & & & $x$ & & & 5 \\
\hline $\mathrm{DlO} 2$ & $x$ & & & & & $x$ & $x$ & $x$ & & & & & & $x$ & 5 \\
\hline FHL1 & $x$ & & & & $x$ & $x$ & $x$ & $x$ & & & & & & & 5 \\
\hline LMOD1 & $x$ & & & & & & $x$ & $x$ & & & & $x$ & & $x$ & 5 \\
\hline NR4A3 & & & & $x$ & $x$ & $x$ & & $x$ & & & & $x$ & & & 5 \\
\hline SPARCL1 & $x$ & & & & $x$ & & $x$ & $x$ & & & $x$ & & & & 5 \\
\hline ZFP36 & & & & & $x$ & $x$ & $x$ & $x$ & & & & $x$ & & & 5 \\
\hline CCND2 & $x$ & & & & $x$ & & $x$ & $x$ & & & & $x$ & & & 5 \\
\hline DKFZP56400823 & $x$ & & & & $x$ & & $x$ & $x$ & & & & & & $x$ & 5 \\
\hline FXYD3 & $x$ & $x$ & & & & $x$ & $x$ & $x$ & & & & & & & 5 \\
\hline MCL1 & & & & & $x$ & & $x$ & $x$ & & & & $x$ & $x$ & & 5 \\
\hline PPP1R12B & $x$ & & & & $X$ & & $x$ & $x$ & & & & & & $x$ & 5 \\
\hline SPG20 & & & & & $x$ & $x$ & $x$ & $x$ & & & $x$ & & & & 5 \\
\hline BTG2 & $x$ & & & & $X$ & $x$ & $x$ & $x$ & & & & $x$ & & & 6 \\
\hline JUND & $x$ & & & $x$ & $x$ & $x$ & & $x$ & & & & $x$ & & & 6 \\
\hline KCNMB1 & $x$ & & & & $X$ & & $x$ & $x$ & & & & $x$ & & $x$ & 6 \\
\hline MYH11 & $x$ & & & & $x$ & & $x$ & $x$ & & & & $x$ & & $x$ & 6 \\
\hline MYLK & $x$ & & & & $X$ & & $x$ & $x$ & & & & $x$ & & $x$ & 6 \\
\hline SOD3 & $x$ & & & & $X$ & $x$ & & $x$ & & & & & $x$ & $x$ & 6 \\
\hline TPM2 & $x$ & & & & $x$ & & $X$ & $x$ & & $x$ & $x$ & $x$ & & $x$ & 8 \\
\hline
\end{tabular}

The studies in which each gene is differentially expressed are given as an $\times$ under the study number, as given in Table 1. "Num studies" refers to the total number of studies in which the gene is significantly differentially expressed with a Q-value $<0.1$.

datasets increases. For instance, in the field of metastasis, this method could be used to compare patients with primary tumors that are metastatic versus non-metastatic. This may add to the information we have learned from the present study. At the time when study was started, the Oncomine database did not provide enough detailed clinical information to perform this analysis. However, this may be feasible in the future.

\section{Limitations}

As with any meta-analysis, the results are dependent upon the reliability of the original data [6]. However, it was difficult to test the validity of the original experiments without raw data. This quality issue was partially overcome by the use of our criteria to select the studies for the meta-analysis and by the use of the meta-analysis approach itself. Our selection criteria excluded the outliers in our analysis, such as datasets without any significant genes with a Q-value less than 0.1 and those with greater than $50 \%$ of the tested genes being significant which we hypothesize might be due to systemic bias rather than true differences. Additionally, the process of combining different studies into one analysis should theoretically minimize the effect of some of the possible confounders or quality issues that may be present in certain studies. Since any gene in our signature had to be repeated in multiple studies (i.e. in four or more for the down-regulated genes), no one study alone could completely invalidate our gene list. Clinical metaanalyses often test for heterogeneity of studies, but this approach has not been extended to the meta-analysis of genomic studies.

There are several areas for improvement that could be addressed in future studies. One limitation we had to overcome was the fact that it was not possible to download the complete datasets from the Oncomine database, 
Table 4 Ingenuity canonical pathways significantly (B-H p-value $<0.05$ ) represented by the genes down-regulated in the common metastatic signature

\begin{tabular}{llll}
\hline Ingenuity Canonical Pathways & $\begin{array}{l}\text { Fisher Exact } \\
\text { p-value }\end{array}$ & $\begin{array}{l}\text { B-H } \\
\text { p-value }\end{array}$ & Ratio \\
\hline Actin Cytoskeleton Signaling & $7.94 \mathrm{E}-08$ & $1.51 \mathrm{E}-05$ & $4.26 \mathrm{E}-02$ \\
Regulation of Actin-based Motility by Rho & $3.89 \mathrm{E}-06$ & $2.14 \mathrm{E}-04$ & $6.52 \mathrm{E}-02$ \\
Integrin Signaling & $4.57 \mathrm{E}-06$ & $2.14 \mathrm{E}-04$ & $3.96 \mathrm{E}-02$ \\
Calcium Signaling & $2.24 \mathrm{E}-05$ & $7.08 \mathrm{E}-04$ & $3.41 \mathrm{E}-02$ \\
Protein Kinase A Signaling & $1.12 \mathrm{E}-04$ & $3.02 \mathrm{E}-03$ & $2.51 \mathrm{E}-02$ \\
RhoA Signaling & $1.86 \mathrm{E}-04$ & $4.27 \mathrm{E}-03$ & $4.55 \mathrm{E}-02$ \\
NRF2-mediated Oxidative Stress Response & $2.00 \mathrm{E}-04$ & $3.28 \mathrm{E}-02$ \\
ILK Signaling & $2.51 \mathrm{E}-04$ & $3.23 \mathrm{E}-02$ \\
Thrombin Signaling & $3.39 \mathrm{E}-04$ & $2.94 \mathrm{E}-02$ \\
Chemokine Signaling & $4.17 \mathrm{E}-04$ & $4.68 \mathrm{E}-03$ & $5.33 \mathrm{E}-02$ \\
VEGF Signaling & $8.32 \mathrm{E}-04$ & $5.75 \mathrm{E}-03$ & $4.12 \mathrm{E}-02$ \\
FAK Signaling & $8.71 \mathrm{E}-04$ & $6.61 \mathrm{E}-03$ & $4.00 \mathrm{E}-02$ \\
Phospholipase C Signaling & $9.12 \mathrm{E}-04$ & $1.07 \mathrm{E}-02$ & $2.34 \mathrm{E}-02$ \\
CAMP-mediated Signaling & $1.02 \mathrm{E}-03$ & $1.07 \mathrm{E}-02$ & $3.11 \mathrm{E}-02$ \\
Tight Junction Signaling & $1.15 \mathrm{E}-03$ & $1.07 \mathrm{E}-02$ & $2.99 \mathrm{E}-02$ \\
Relaxin Signaling & $3.47 \mathrm{E}-03$ & $1.15 \mathrm{E}-02$ & $2.68 \mathrm{E}-02$ \\
CDK5 Signaling & $9.12 \mathrm{E}-03$ & $1.20 \mathrm{E}-02$ & $3.19 \mathrm{E}-02$ \\
IL-8 Signaling & $9.33 \mathrm{E}-03$ & $2.95 \mathrm{E}-02$ & $2.15 \mathrm{E}-02$ \\
\hline
\end{tabular}

$\mathrm{B}-\mathrm{H}$ : Benjamini-Hochberg method for correcting for the multiple testing problem; Ratio: The number of genes from the metastatic signature that map to the pathway divided by the total number of genes that map to the canonical pathway.

and we were unable to find raw data for most of older studies included in our signature. Therefore, we were unable to compare the complete lists of genes tested and potentially capture genes that were only represented in a small number of platforms by performing more advanced meta-analysis methods, specifically one that could provide weighting based on the number of genes and samples in the initial experiment, such as the weighted z-method [57]. Limiting the study to only those datasets with available raw data would have substantially reduced the number of studies and possibly the power to detect genes of interest. The counting method we performed in this study was only dependent on information of the significant gene lists which allowed the use of the maximum number of array studies. In the future, as more datasets are readily available for download, this problem may be overcome. This current limitation, however, does not affect the conclusion that those genes identified in this study are likely to be of importance. We conclude that this method has good specificity but may have less sensitivity (a higher false negative rate) than other meta-analysis approaches.

Inconsistent gene ontology also complicated the analysis in this study. Since the Oncomine database provides only the Gene Symbol and only one other gene identifier that could not be matched for every dataset, the only common identifier between our validation datasets and the datasets used in the meta-analysis was the gene symbol. However, a gene symbol may map to multiple probes, so we could be counting results of different probes in each dataset. We did ensure that we counted each unique gene symbol only once in each direction by manually removing duplicates in our extracted data prior to running the meta-analysis. In addition, the use of gene symbols forced us to eliminate from our comparison many ESTs that could have been found in multiple studies. This highlights the need for a common identifier standardized across platforms, such as Entrez gene IDs, which will help to identify more common metastatic genes.

Lastly, the majority of studies used in the meta-analysis were from epithelial tumors reflecting their predominance in the population and, hence, the microarray studies. Attempts to remove these epithelial cancer datasets, such as prostate cancers, resulted in lack of power to identify significant metastatic genes. This could be due to a more dramatic biological effect of metastasis in these epithelial tumors, or the power of the studies themselves, such as a larger sample size and less tissue heterogeneity, etc. This is a limitation of our study due to the availability of eligible datasets in the Oncomine database. With the accumulation of more datasets for non-epithelial, non-adenocarcinoma tumors, future studies may be able to incorporate them and identify a more refined common signature of metastasis that is applicable to even more tumor types. 


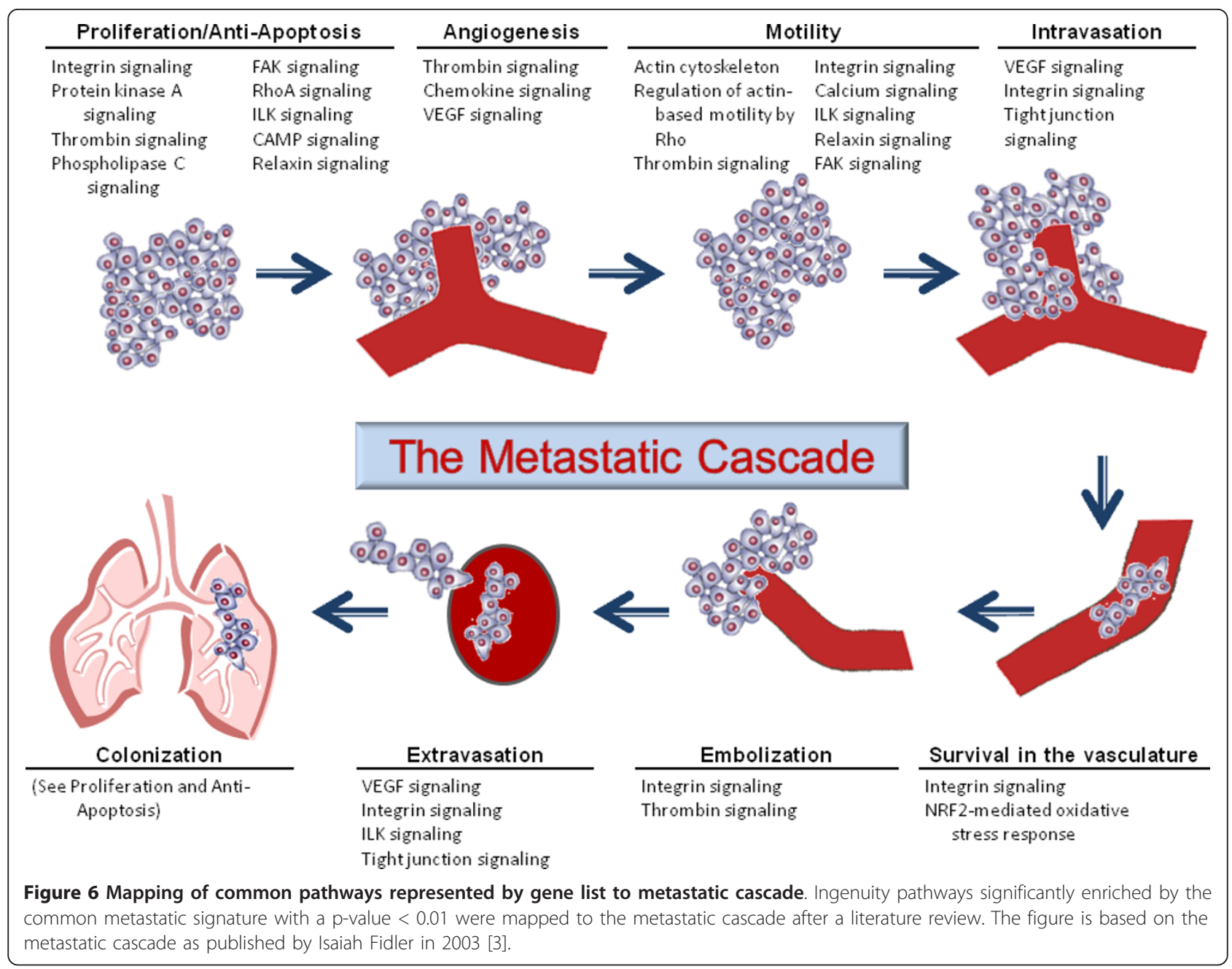

Table 5 Enrichment of the common metastatic-signature (CMS)

\begin{tabular}{|c|c|c|c|c|c|c|c|c|}
\hline $\begin{array}{c}\text { Study } \\
\text { [Reference] }\end{array}$ & Platform & $\begin{array}{l}\text { Unique Genes } \\
\text { Tested }\end{array}$ & $\begin{array}{l}\text { Primary } \\
\text { Tumors }\end{array}$ & $\begin{array}{l}\text { Distant } \\
\text { Mets }\end{array}$ & $\begin{array}{l}\text { Unique CMS Genes } \\
\text { in dataset }\end{array}$ & $\begin{array}{l}\text { Significant } \\
\text { CMS Genes }\end{array}$ & $\begin{array}{c}\text { LS } \\
\text { Statistic } \\
\text { p-value }\end{array}$ & $\begin{array}{l}\text { GEO Acc \# or } \\
\text { SMD Pub \# }\end{array}$ \\
\hline $\begin{array}{l}\text { Varambally } \\
\text { Prostate [39] }\end{array}$ & HG U133 Plus 2.0 & 19079 & 7 & 6 & 65 & 57 & $\begin{array}{c}<< \\
0.00001\end{array}$ & GSE3325 \\
\hline $\begin{array}{c}\text { Chen Gastric } \\
{[15]}\end{array}$ & $\begin{array}{l}\text { Undefined cDNA } \\
\text { microarray }\end{array}$ & 10568 & 89 & 14 & 61 & 26 & 0.00001 & SMD Pub \# 232 \\
\hline Ki Colon [21] & CMRC-GT & 9078 & 52 & 28 & 55 & 25 & 0.00011 & GSE6988 \\
\hline $\begin{array}{c}\text { Riker Melanoma } \\
\text { [33] }\end{array}$ & HG U133 Plus 2.0 & 19079 & 16 & 40 & 71 & 17 & 0.011 & GSE7553 \\
\hline $\begin{array}{c}\text { Linn Sarcoma } \\
{[25]}\end{array}$ & $\begin{array}{l}\text { Undefined CDNA } \\
\text { microarray }\end{array}$ & 14437 & 47 & 10 & 61 & 5 & 0.50 & SMD Pub \# 287 \\
\hline $\begin{array}{c}\text { Tothill Ovarian } \\
\text { [37] }\end{array}$ & HG U133 Plus 2.0 & 19079 & 189 & 54 & 65 & 7 & 0.93 & GSE9899 \\
\hline
\end{tabular}

The 6 validation datasets with regard to the platform used in the original experiment, the number of unique genes represented in the platform, the number of samples that are primary tumors or distant metastases (mets), the number of genes in the common metastatic signature (CMS) represented in the platform, the number of CMS genes that were significant with a Q-value $<0.1$, the LS statistic p-value, and the Gene Expression Omnibus Accession number (GEO Acc \#) or SMD Publication number (SMD Pub \#). HG U133 Plus 2: Affymetrix Human Genome U133 Plus 2.0 Array; CMRC-GT: Cancer Metastasis Research Center-Genomic Tree array, Yonsei Cancer Center, Seoul, Korea. 


\section{Conclusions}

We have developed a modified meta-analysis counting method and applied it to the comparison of primary tumors versus metastases in various tumor types. We identified a list of 78 down-regulated genes and 1 upregulated gene in metastases compared to primary tumors with a False Discovery Proportion of less than 0.1 . Many of these genes are involved in pathways associated with metastasis. After comparing the list of genes generated by our analysis with six independent datasets testing primaries versus metastases, we found that four of the datasets demonstrated that these genes were dysregulated than would be expected by chance alone (i.e. LS-statistic $\mathrm{p}$-value $<0.05)$. We believe that the identification of this common metastatic signature could facilitate further research in metastasis, such as outcome prediction, drug discovery, and other functional studies.

We have followed the relevant components of the PRISMA 2009 guidelines in the preparation of this manuscript [58].

\section{Funding}

This work was supported by the NIH Training Grant T32 CA115303 (MHD), NCI grants R33 CA97874-05 (SGH) and U01 CA114757-04 (CCL), the Gillson Longenbaugh Foundation (CCL) and Cancer Prevention and Research Institute of Texas (TKM).

\section{Acknowledgements}

We are grateful to Dr. Javed Khan for helpful discussion. We would like to thank Dr. Lisa Wang for her detailed review of this manuscript, and Donna Espadas for her help with preparing figures for the paper.

\section{Author details}

${ }^{1}$ Dan L. Duncan Cancer Center, Baylor College of Medicine, One Baylor Plaza, Houston, Texas, 77030, USA. ${ }^{2}$ Texas Children's Cancer Center, Department of Pediatrics, Baylor College of Medicine, 6701 Fannin Street, Suite 1410, Houston, Texas, 77030, USA. ${ }^{3}$ Breast Center, Baylor College of Medicine, One Baylor Plaza, Houston, Texas, 77030, USA.

\section{Authors' contributions}

MHD performed the dataset identification and retrieval, programmed the method in the R environment, performed pathway analysis and validation, and drafted the manuscript. SGH helped refine the meta-analysis method and advised on data display. CCL aided in the study design, data analysis, and in the interpretation of results. TKM conceived of, supervised, designed and coordinated the study, and revised the manuscript. All authors read and approved the final manuscript.

\section{Competing interests}

The authors declare that they have no competing interests.

Received: 21 September 2010 Accepted: 7 July 2011

Published: 7 July 2011

\section{References}

1. Sleeman J, Steeg PS: Cancer metastasis as a therapeutic target. Eur J Cancer 46:1177-1180.

2. Sporn MB: The war on cancer: a review. Ann N Y Acad Sci 1997, 833:137-146.
3. Fidler IJ: The pathogenesis of cancer metastasis: the 'seed and soil' hypothesis revisited. Nat Rev Cancer 2003, 3:453-458.

4. Shevde LA, Welch DR: Metastasis suppressor pathways-an evolving paradigm. Cancer Lett 2003, 198:1-20.

5. Ramaswamy S, Ross KN, Lander ES, Golub TR: A molecular signature of metastasis in primary solid tumors. Nat Genet 2003, 33:49-54.

6. Hong F, Breitling R: A comparison of meta-analysis methods for detecting differentially expressed genes in microarray experiments. Bioinformatics 2008, 24:374-382.

7. Rhodes DR, Yu J, Shanker K, Deshpande N, Varambally R, Ghosh D, Barrette T, Pandey A, Chinnaiyan AM: Large-scale meta-analysis of cancer microarray data identifies common transcriptional profiles of neoplastic transformation and progression. Proc Natl Acad Sci USA 2004, 101:9309-9314.

8. Parmigiani G, Garrett-Mayer ES, Anbazhagan R, Gabrielson E: A cross-study comparison of gene expression studies for the molecular classification of lung cancer. Clin Cancer Res 2004, 10:2922-2927.

9. Oncomine 4.3 Research Edition. [http://www.oncomine.org].

10. Rhodes DR, Yu J, Shanker K, Deshpande N, Varambally R, Ghosh D, Barrette T, Pandey A, Chinnaiyan AM: ONCOMINE: a cancer microarray database and integrated data-mining platform. Neoplasia 2004, 6:1-6.

11. Rhodes DR, Kalyana-Sundaram S, Mahavisno V, Varambally R, Yu J, Briggs BB, Barrette TR, Anstet MJ, Kincead-Beal C, Kulkarni P, Varambally S, Ghosh D, Chinnaiyan AM: Oncomine 3.0: genes, pathways, and networks in a collection of 18,000 cancer gene expression profiles. Neoplasia 2007, 9:166-180.

12. Adib TR, Henderson S, Perrett C, Hewitt D, Bourmpoulia D, Ledermann J, Boshoff C: Predicting biomarkers for ovarian cancer using geneexpression microarrays. Br J Cancer 2004, 90:686-692.

13. Bhattacharjee A, Richards WG, Staunton J, Li C, Monti S, Vasa P, Ladd C, Beheshti J, Bueno R, Gillette M, Loda M, Weber G, Mark EJ, Lander ES, Wong W, Johnson BE, Golub TR, Sugarbaker DJ, Meyerson M: Classification of human lung carcinomas by mRNA expression profiling reveals distinct adenocarcinoma subclasses. Proc Natl Acad Sci USA 2001, 98:13790-13795.

14. International Genomics Consortium Expression Project for Oncology. [http://www.intgen.org/expo/publicly-available-data/].

15. Chen X, Leung SY, Yuen ST, Chu KM, Ji J, Li R, Chan AS, Law S, Troyanskaya OG, Wong J, So S, Botstein D, Brown PO: Variation in gene expression patterns in human gastric cancers. Mol Biol Cell 2003, 14:3208-3215.

16. Garber ME, Troyanskaya OG, Schluens K, Petersen S, Thaesler Z, PacynaGengelbach M, van de Rijn M, Rosen GD, Perou CM, Whyte Rl, Altman RB, Brown PO, Botstein D, Petersen I: Diversity of gene expression in adenocarcinoma of the lung. Proc Natl Acad Sci USA 2001, 98:13784-13789.

17. Graudens E, Boulanger V, Mollard C, Mariage-Samson R, Barlet X, Gremy G, Couillault C, Lajemi M, Piatier-Tonneau D, Zaborski P, Eveno E, Auffray C, Imbeaud S: Deciphering cellular states of innate tumor drug responses. Genome Biol 2006, 7:R19.

18. Haqq C, Nosrati M, Sudilovsky D, Crothers J, Khodabakhsh D, Pulliam BL, Federman S, Miller JR, Allen RE, Singer MI, Leong SP, Ljung BM, Sagebiel RW, Kashani-Sabet M: The gene expression signatures of melanoma progression. Proc Natl Acad Sci USA 2005, 102:6092-6097.

19. Holzbeierlein J, Lal P, LaTulippe E, Smith A, Satagopan J, Zhang L, Ryan C, Smith S, Scher H, Scardino P, Reuter V, Gerald WL: Gene expression analysis of human prostate carcinoma during hormonal therapy identifies androgen-responsive genes and mechanisms of therapy resistance. Am J Pathol 2004, 164:217-227.

20. Jain S, Watson MA, DeBenedetti MK, Hiraki Y, Moley JF, Milbrandt J: Expression profiles provide insights into early malignant potential and skeletal abnormalities in multiple endocrine neoplasia type $2 \mathrm{~B}$ syndrome tumors. Cancer Res 2004, 64:3907-3913.

21. Ki DH, Jeung HC, Park CH, Kang SH, Lee GY, Lee WS, Kim NK, Chung HC, Rha SY: Whole genome analysis for liver metastasis gene signatures in colorectal cancer. Int J Cancer 2007, 121:2005-2012.

22. Lapointe J, Li C, Higgins JP, van de Rijn M, Bair E, Montgomery K, Ferrari M, Egevad L, Rayford W, Bergerheim U, Ekman P, DeMarzo AM, Tibshirani R, Botstein D, Brown PO, Brooks JD, Pollack JR: Gene expression profiling identifies clinically relevant subtypes of prostate cancer. Proc Natl Acad Sci USA 2004, 101:811-816. 
23. LaTulippe E, Satagopan J, Smith A, Scher H, Scardino P, Reuter V, Gerald WL: Comprehensive gene expression analysis of prostate cancer reveals distinct transcriptional programs associated with metastatic disease. Cancer Res 2002, 62:4499-4506.

24. Liao YL, Sun YM, Chau GY, Chau YP, Lai TC, Wang JL, Horng JT, Hsiao M, Tsou AP: Identification of SOX4 target genes using phylogenetic footprinting-based prediction from expression microarrays suggests that overexpression of SOX4 potentiates metastasis in hepatocellular carcinoma. Oncogene 2008, 27:5578-5589.

25. Linn SC, West RB, Pollack JR, Zhu S, Hernandez-Boussard T, Nielsen TO, Rubin BP, Patel R, Goldblum JR, Siegmund D, Botstein D, Brown PO, Gilks CB, van de Rijn M: Gene expression patterns and gene copy number changes in dermatofibrosarcoma protuberans. Am J Pathol 2003, 163:2383-2395.

26. Magee JA, Araki T, Patil S, Ehrig T, True L, Humphrey PA, Catalona WJ, Watson MA, Milbrandt J: Expression profiling reveals hepsin overexpression in prostate cancer. Cancer Res 2001, 61:5692-5696.

27. Nakayama R, Nemoto T, Takahashi H, Ohta T, Kawai A, Seki K, Yoshida T, Toyama $Y$, Ichikawa $H$, Hasegawa T: Gene expression analysis of soft tissue sarcomas: characterization and reclassification of malignant fibrous histiocytoma. Mod Pathol 2007, 20:749-759.

28. Nielsen TO, West RB, Linn SC, Alter O, Knowling MA, O'Connell JX, Zhu S, Fero M, Sherlock G, Pollack JR, Brown PO, Botstein D, van de Rijn M: Molecular characterisation of soft tissue tumours: a gene expression study. Lancet 2002, 359:1301-1307.

29. Ohali A, Avigad S, Zaizov R, Ophir R, Horn-Saban S, Cohen IJ, Meller I, Kollender Y, Issakov J, Yaniv I: Prediction of high risk Ewing's sarcoma by gene expression profiling. Oncogene 2004, 23:8997-9006.

30. O'Donnell RK, Kupferman M, Wei SJ, Singhal S, Weber R, O'Malley B, Cheng Y, Putt M, Feldman M, Ziober B, Muschel RJ: Gene expression signature predicts lymphatic metastasis in squamous cell carcinoma of the oral cavity. Oncogene 2005, 24:1244-1251.

31. Radvanyi L, Singh-Sandhu D, Gallichan S, Lovitt C, Pedyczak A, Mallo G, Gish K, Kwok K, Hanna W, Zubovits J, Armes J, Venter D, Hakimi J, Shortreed J, Donovan M, Parrington M, Dunn P, Oomen R, Tartaglia J, Berinstein NL: The gene associated with trichorhinophalangeal syndrome in humans is overexpressed in breast cancer. Proc Natl Acad Sci USA 2005, 102:11005-11010

32. Ramaswamy $S$, Tamayo $P$, Rifkin $R$, Mukherjee $S$, Yeang $C H$, Angelo $M$, Ladd C, Reich M, Latulippe E, Mesirov JP, Poggio T, Gerald W, Loda M, Lander ES, Golub TR: Multiclass cancer diagnosis using tumor gene expression signatures. Proc Natl Acad Sci USA 2001, 98:15149-15154.

33. Riker Al, Enkemann SA, Fodstad O, Liu S, Ren S, Morris C, Xi Y, Howell P, Metge B, Samant RS, Shevde LA, Li W, Eschrich S, Daud A, Ju J, Matta J: The gene expression profiles of primary and metastatic melanoma yields a transition point of tumor progression and metastasis. BMC Med Genomics 2008, 1:13

34. Segal NH, Pavlidis P, Noble WS, Antonescu CR, Viale A, Wesley UV, Busam K, Gallardo H, DeSantis D, Brennan MF, Cordon-Cardo C, Wolchok JD, Houghton AN: Classification of clear-cell sarcoma as a subtype of melanoma by genomic profiling. J Clin Oncol 2003, 21:1775-1781.

35. Segal NH, Pavlidis P, Antonescu CR, Maki RG, Noble WS, DeSantis $D$, Woodruff JM, Lewis JJ, Brennan MF, Houghton AN, Cordon-Cardo C Classification and subtype prediction of adult soft tissue sarcoma by functional genomics. Am J Pathol 2003, 163:691-700.

36. Sorlie T, Tibshirani R, Parker J, Hastie T, Marron JS, Nobel A, Deng S, Johnsen H, Pesich R, Geisler S, Demeter J, Perou CM, Lonning PE, Brown PO, Borresen-Dale AL, Botstein D: Repeated observation of breast tumor subtypes in independent gene expression data sets. Proc Natl Acad Sci USA 2003, 100:8418-8423.

37. Tothill RW, Tinker AV, George J, Brown R, Fox SB, Lade S, Johnson DS, Trivett MK, Etemadmoghadam D, Locandro B, Traficante N, Fereday S, Hung JA, Chiew YE, Haviv I, Gertig D, DeFazio A, Bowtell DD: Novel molecular subtypes of serous and endometrioid ovarian cancer linked to clinical outcome. Clin Cancer Res 2008, 14:5198-5208.

38. Vanaja DK, Cheville JC, Iturria SJ, Young CY: Transcriptional silencing of zinc finger protein 185 identified by expression profiling is associated with prostate cancer progression. Cancer Res 2003, 63:3877-3882.

39. Varambally S, Yu J, Laxman B, Rhodes DR, Mehra R, Tomlins SA, Shah RB, Chandran U, Monzon FA, Becich MJ, Wei JT, Pienta KJ, Ghosh D, Rubin MA, Chinnaiyan AM: Integrative genomic and proteomic analysis of prostate cancer reveals signatures of metastatic progression. Cancer Cell 2005, 8:393-406.

40. Weigelt B, Glas AM, Wessels LF, Witteveen AT, Peterse JL, van't Veer LJ: Gene expression profiles of primary breast tumors maintained in distant metastases. Proc Natl Acad Sci USA 2003, 100:15901-15905.

41. Xu L, Shen SS, Hoshida Y, Subramanian A, Ross K, Brunet JP, Wagner SN, Ramaswamy S, Mesirov JP, Hynes RO: Gene expression changes in an animal melanoma model correlate with aggressiveness of human melanoma metastases. Mol Cancer Res 2008, 6:760-769.

42. Ye QH, Qin LX, Forgues M, He P, Kim JW, Peng AC, Simon R, Li Y, Robles Al, Chen Y, Ma ZC, Wu ZQ, Ye SL, Liu YK, Tang ZY, Wang XW: Predicting hepatitis $B$ virus-positive metastatic hepatocellular carcinomas using gene expression profiling and supervised machine learning. Nat Med 2003, 9:416-423.

43. Yu YP, Landsittel D, Jing L, Nelson J, Ren B, Liu L, McDonald C, Thomas R, Dhir R, Finkelstein S, Michalopoulos G, Becich M, Luo JH: Gene expression alterations in prostate cancer predicting tumor aggression and preceding development of malignancy. J Clin Oncol 2004, 22:2790-2799.

44. R Development Core Team: R: A Language and Environment for Statistical Computing. Vienna, Austria: R Foundation for Statistical Computing; 2010.

45. Ingenuity ${ }^{\circledR}$ Systems. [http://www.ingenuity.com].

46. Benjamini Y, Hochberg Y: Controlling the False Discovery Rate: A Practical and Powerful Approach to Multiple Testing. Journal of the Royal Statistical Society B 1995, 57:289-300.

47. Simon R, Lam A, Li MC, Ngan M, Menenzes S, Zhao Y: Analysis of Gene Expression Data Using BRB-Array Tools. Cancer Inform 2007, 3:11-17.

48. Xu X, Zhao Y, Simon R: Gene Set Expression Comparison kit for BRBArrayTools. Bioinformatics 2008, 24:137-139.

49. Edgar R, Domrachev M, Lash AE: Gene Expression Omnibus: NCBI gene expression and hybridization array data repository. Nucleic Acids Res 2002, 30:207-210.

50. Hubble J, Demeter J, Jin H, Mao M, Nitzberg M, Reddy TB, Wymore F, Zachariah ZK, Sherlock G, Ball CA: Implementation of GenePattern within the Stanford Microarray Database. Nucleic Acids Res 2009, 37:D898-901.

51. Lamb J, Crawford ED, Peck D, Modell JW, Blat IC, Wrobel MJ, Lerner J, Brunet JP, Subramanian A, Ross KN, Reich M, Hieronymus $H$, Wei G, Armstrong SA, Haggarty SJ, Clemons PA, Wei R, Carr SA, Lander ES, Golub TR: The Connectivity Map: using gene-expression signatures to connect small molecules, genes, and disease. Science 2006, 313:1929-1935.

52. Lamb J: The Connectivity Map: a new tool for biomedical research. Nat Rev Cancer 2007, 7:54-60.

53. Venditto VJ, Simanek EE: Cancer therapies utilizing the camptothecins: a review of the in vivo literature. Mol Pharm 7:307-349.

54. Zhang L, Yu J, Pan H, Hu P, Hao Y, Cai W, Zhu H, Yu AD, Xie X, Ma D, Yuan J: Small molecule regulators of autophagy identified by an imagebased high-throughput screen. Proc Natl Acad Sci USA 2007, 104:19023-19028.

55. Albini A, Mirisola V, Pfeffer U: Metastasis signatures: genes regulating tumor-microenvironment interactions predict metastatic behavior. Cancer Metastasis Rev 2008, 27:75-83.

56. Rinker-Schaeffer CW, O'Keefe JP, Welch DR, Theodorescu D: Metastasis suppressor proteins: discovery, molecular mechanisms, and clinical application. Clin Cancer Res 2006, 12:3882-3889.

57. Whitlock MC: Combining probability from independent tests: the weighted Z-method is superior to Fisher's approach. J Evol Biol 2005, 18:1368-1373.

58. Moher D, Liberati A, Tetzlaff J, Altman DG: Preferred reporting items for systematic reviews and meta-analyses: the PRISMA statement. PLOS Med 2009, 6:e1000097.

Pre-publication history

The pre-publication history for this paper can be accessed here: http://www.biomedcentral.com/1755-8794/4/56/prepub

doi:10.1186/1755-8794-4-56

Cite this article as: Daves et al:: Meta-analysis of multiple microarray datasets reveals a common gene signature of metastasis in solid tumors. BMC Medical Genomics 2011 4:56 